\title{
Technological Change and Catching-Up in the Indian Banking Sector: A Time-Dependent Nonparametric Frontier Approach
}

\author{
Sushanta Mallick ${ }^{1}$ (D) $\cdot$ Aarti Rughoo ${ }^{2} \cdot$ Nickolaos G. Tzeremes $^{3} \cdot$ Wei Xu $^{4}$
}

Accepted: 4 May 2020 / Published online: 18 May 2020

(c) The Author(s) 2020

\begin{abstract}
This paper investigates whether there has been any improvement in efficiency convergence of banks in India during the post-reform period considering bank ownership structures, using a balanced panel for 73 banks over the time period 19962014. Utilizing nonparametric frontier estimators, we compute time-dependent bank efficiency scores, which allow us to examine the dynamics of technological frontier and catch-up levels of Indian banks, and to explore the convergence patterns in the estimated efficiency levels. Our results signify that the state-owned banks, which dominate the banking activity in India, establish themselves as the best performers, ahead of the private, foreign and cooperative banks during post-2005. Even during the recent global financial crisis period, we find that bank efficiency levels increased, except for foreign banks which have had the greatest adverse impact. The convergence results show that heterogeneity is present in bank efficiency convergence, which points to the presence of club formation suggesting that Indian banks' efficiency convergence is partly driven by the ownership structure.
\end{abstract}

Keywords Bank efficiency · Nonparametric frontiers · Conditional efficiency · Convergence $\cdot$ India

JEL Classification $\mathrm{C} 14 \cdot \mathrm{G} 21 \cdot \mathrm{G} 28$

\section{Introduction}

The first significant systemic changes of the Indian banking system can be traced back to the late 1960s when banks were nationalised. It has been argued that these changes were introduced rather chaotically having a weak impact on the reform of Indian banks (Fujii et al. 2014). Subsequently, it was felt that the positive and

Sushanta Mallick

s.k.mallick@qmul.ac.uk

Extended author information available on the last page of the article 
systematic changes were only introduced in the 1990s in the form of the Narasimham Committee reports of 1991 and 1998, which outlined the main trajectory of further improvements. The main aim of the reforms was the promotion of competition and market orientation promoting banks' efficiency improvements (Kumar 2013). The related literature investigates bank efficiency in India during the last two decades (Kumbhakar and Sarkar 2003; Bhaumik and Dimova 2004; Das and Ghosh 2006; Bhattacharyya and Pal 2013, among others). However, there are limited studies investigating bank performance in India in the more recent years (Fujii et al. 2014; Tzeremes 2015). Additionally, the empirical investigation of convergence patterns among Indian banks' efficiency levels is largely an unexplored area in the related literature (Kumar and Gulati 2010; Kumar 2013).

In contrast to the related literature on the deregulation and efficiency in Indian banking, this paper makes some important contributions. First, we analyse bank efficiency using a time-dependent non-parametric frontier approach (Bădin et al. 2012; Mastromarco and Simar 2015). This novel approach does not presume that the restrictive "separability" condition among the inputs, the outputs and the time holds (Simar and Wilson 2007, 2011; Daraio et al. 2018). As a result, we assume that time influences banks' inefficiency levels along with the shape and the level of the boundary of the attainable set. These measures enable us to incorporate dynamic effects on the estimated efficiency measures, grasping all the performance changes that are based on different time periods (Mallick et al. 2016; Mastromarco and Simar 2018; Tzeremes 2015, 2019). The applied efficiency estimators are most suited in our case since they enable us to identify the indirect effect of the reforms made over different time periods.

The second part of the paper then tests for convergence in bank efficiency scores using the group and club convergence methods of Phillips and Sul (2007, 2009). This is a robust approach being most suitable for nonparametric efficiency estimators, since it does not impose strong assumptions on the trend nor on the stochastic stationarity of the examined efficiency estimates (Chen et al. 2018). Third, we conduct a comprehensive study by factoring all types of bank ownership structures in our analysis. We thus analyse banks' efficiency levels on the basis of their ownership structures and test whether bank ownership structure influences the convergence process. Fourth, we are able to draw meaningful conclusions by considering a long dataset (1996-2014) that covers the entire reform period in India while spanning over the global financial crisis period.

The paper is structured in the following manner. Section 2 provides a summary of the related literature, whereas Sect. 3 discusses the methodological framework. In Sect. 4, we describe the data and present the empirical findings. Finally, Sect. 5 concludes the paper.

\section{A Brief Snapshot of the Literature}

Following the financial reforms during post-1991, considerable research examining efficiency of Indian banks has emerged. The literature follows two main trajectories. First, several studies examine bank efficiency and productivity within 
the context of various bank ownership structures (Sarkar et al. 1998; Bhaumik and Dimova 2004). Second, a large strand of studies examines the effect of restructuring process on banks' stability, efficiency and productivity levels (Kumbhakar and Sarkar 2003; Tabak and Tecles 2010; Das and Kumbhakar 2012; Ahamed and Mallick 2017a, b). Most of these studies looking at bank efficiency following the reforms point to low and declining efficiency. For instance, Das and Ghosh (2006) have found low levels of technical efficiency coupled with a declining trend in efficiency. Similarly, the empirical evidence from Battacharyya and Pal (2013) indicates low and declining efficiency for most years, though an improvement was noted towards 2009. In addition, some of the empirical studies revealed varying efficiency levels on the basis of ownership structure. Bhaumik and Dimova (2004) provide evidence of higher performance for domestic private and foreign banks, with the state-owned banks catching-up from mid-1990s.

In their study, Sahoo and Tone (2009) reported that post 2002 all three types of banks experienced an upward trend in efficiency. They attributed the changes to the liberalisation process. Furthermore, they identified weak output and resource allocation performances for nationalised banks. On the other hand, Tabak and Tecles (2010) examined Indian banks' performance levels over the period 2000-2006 and their results suggest the improvement of state-owned banks' efficiency levels in relation to domestic private and foreign banks. According to them, the driving force of this performance change was attributed to the liberalisation policy which in turn enhanced market competition.

In a comparable study, Sanyal and Shankar (2011) over the period 1992-2004 provide evidence that productivity gaps among banks with different ownership have widened after 1998. Fujii et al. (2014) showed that foreign banks perform better than the state-owned and domestic private banks. These results contradict the findings from earlier studies (Sanyal and Shankar 2011; Tabak and Tecles 2010) suggesting that state-owned banks are better performers. In a similar study, Tzeremes (2015) employed a conditional directional distance estimator to estimate bank efficiency over the period 2004-2012. The author confirmed previous findings that a bank's ownership structure has a direct impact on its performance level. The study reported that the overall banking efficiency increased in India during the period 2004-2008, but decreased thereafter.

Stemming from the studies examining the effect of deregulation on the banking industry, Sensarma (2008) found that banks' efficiency and productivity levels have declined as a result of the deregulation policies. In contrast, Das and Kumbhakar (2012) in a different methodological framework provide evidence of a positive impact of deregulation on banks' efficiency levels. Casu et al. (2013) suggest that banks' ownership structure influences the way the banks' responded to the deregulation reforms, suggesting that foreign banks dominate the banking activity in India.

To our knowledge, Kumar and Gulati (2010) and Kumar (2013) are the only studies, so far, that analysed the convergence of Indian banks' efficiency levels. Specifically, Kumar and Gulati (2010) applied the concept of beta and sigma convergence to a sample of Indian public sector banks (PSBs) providing evidence of increased bank efficiency during the post reform period. Similarly, Kumar (2013) extended the 
study by Kumar and Gulati (2010) providing empirical evidence of a positive effect of deregulation policies on banks' efficiency levels.

During the post reform period, both studies confirmed the presence of convergence among Indian banks' efficiency levels, which requires re-examination, measuring efficiency in a time-dependent non-parametric set-up, while also considering the ownership structures.

\section{Data and Methodology}

\subsection{Data Description}

We model Indian banks' production process utilizing the intermediation approach (Berger and Humphrey 1997). As a result, we argue that banks' production process transforms deposits alongside production inputs in order to produce loans and other financial products (Sealey and Lindley 1977). Following the relevant literature (McKillop et al. 1996; Berger and Mester 1997; Drake and Hall 2003; Fukuyama and Matousek 2011; Degl'Innocenti et al. 2017), in our nonparametric efficiency measurement, we need to define banks' production process. For that reason, we use as inputs: total fixed assets, total deposits and wages and salaries, whereas, as output, we use banks' total loans (see Table 1 for descriptive statistics). Finally, our sample contains a balanced panel of 73 Indian banks with different ownership structures over the period 1996-2014.

\subsection{Time-Dependent Efficiency Measures}

By incorporating the developments of the relative literature (Daraio and Simar 2005, 2007; Jeong et al. 2010; Bădin et al. 2012), ${ }^{1}$ we can define bank's production function as a set of inputs $v \in R_{+}^{p}$ and outputs $\kappa \in R_{+}^{q}$. Then the bank's production set of $\Omega$ with all technical feasible pairs of inputs and outputs $(v, \kappa)$ can be defined as:

$$
\Omega=\left\{(v, \kappa) \in R_{+}^{p} \times R_{+}^{q} \mid v \text { can produce } \kappa\right\}
$$

Given a certain input-output level $\left(v_{0}, \kappa_{0} \in \Omega\right)$ the input oriented efficiency score can be presented as:

$$
\vartheta_{0}=\vartheta\left(v_{0}, \kappa_{0}\right)=\inf \left\{\vartheta>0 \mid\left(\vartheta v_{0}, \kappa_{0}\right) \in \Omega\right\} .
$$

In Eq. (2), $\vartheta_{0}$ indicates the input oriented efficiency score and identifies the proportionate reduction of bank's inputs operating at $\left(v_{0}, \kappa_{0}\right)$ level in order to be technically efficient. Furthermore, $\vartheta_{0}$ takes values of $\leq 1$ with a $\vartheta_{0}=1$ suggesting that a bank is

\footnotetext{
${ }^{1}$ For interesting applications using the probabilistic framework of efficiency measurement see the studies by Gearhart III and Michieka (2018) and Cordero et al. (2018).
} 
Table 1 Descriptive statistics

\begin{tabular}{|c|c|c|c|c|c|}
\hline Years & Statistics & Total fixed assets & Total deposits & Wages and salaries & Total loans and securities \\
\hline \multirow[t]{2}{*}{1996} & Mean & $81,378.595$ & $96,301.381$ & 1603.908 & $37,451.552$ \\
\hline & Std & $187,038.155$ & $206,866.035$ & 4193.022 & $87,240.205$ \\
\hline \multirow[t]{2}{*}{1997} & Mean & $91,390.671$ & $106,672.196$ & 1685.832 & $39,315.477$ \\
\hline & Std & $203,710.546$ & $221,257.887$ & 4205.269 & $86,636.885$ \\
\hline \multirow[t]{2}{*}{1998} & Mean & $108,056.634$ & $127,152.582$ & 1835.122 & $46,286.270$ \\
\hline & Std & $235,777.206$ & $262,001.699$ & 4517.937 & $101,528.838$ \\
\hline \multirow[t]{2}{*}{1999} & mean & $129,111.801$ & $150,510.605$ & 2205.518 & $53,582.045$ \\
\hline & Std & $286,877.755$ & $324,311.000$ & 5617.822 & $120,561.449$ \\
\hline \multirow[t]{2}{*}{2000} & Mean & $150,584.001$ & $178,275.385$ & 2453.285 & $64,423.126$ \\
\hline & Std & $332,084.273$ & $378,110.488$ & 5901.275 & $138,337.393$ \\
\hline \multirow[t]{2}{*}{2001} & Mean & $174,848.830$ & $210,142.358$ & 3049.271 & $75,689.201$ \\
\hline & Std & $393,857.644$ & $452,193.471$ & 7618.124 & $157,928.213$ \\
\hline \multirow[t]{2}{*}{2002} & Mean & $207,690.385$ & $245,812.247$ & 2864.804 & $91,157.738$ \\
\hline & Std & $445,491.963$ & $504,579.781$ & 6590.269 & $174,697.918$ \\
\hline \multirow[t]{2}{*}{2003} & Mean & $230,096.737$ & $278,147.078$ & 3125.392 & $103,025.389$ \\
\hline & Std & $481,054.650$ & $562,815.654$ & 7207.918 & $195,657.430$ \\
\hline \multirow[t]{2}{*}{2004} & Mean & $265,560.988$ & $320,683.081$ & 3544.674 & $117,802.533$ \\
\hline & Std & $528,755.218$ & $626,236.174$ & 8124.967 & $221,475.139$ \\
\hline \multirow[t]{2}{*}{2005} & Mean & $310,459.455$ & $392,311.785$ & 3989.668 & $153,182.738$ \\
\hline & Std & $607,234.692$ & $756,195.591$ & 8936.809 & $286,164.267$ \\
\hline \multirow[t]{2}{*}{2006} & Mean & $367,272.164$ & $484,592.290$ & 4407.156 & $202,950.568$ \\
\hline & Std & $690,041.935$ & $900,211.636$ & $10,108.868$ & $379,505.550$ \\
\hline \multirow[t]{2}{*}{2007} & Mean & $457,535.982$ & $618,286.448$ & 4767.977 & $265,319.030$ \\
\hline & Std & $827,387.362$ & $1,118,209.520$ & $10,070.681$ & $493,880.691$ \\
\hline \multirow[t]{2}{*}{2008} & Mean & $572,446.727$ & $766,172.292$ & 5290.595 & $330,984.708$ \\
\hline & Std & $1,027,509.681$ & $1,354,028.759$ & $10,120.402$ & $601,368.230$ \\
\hline \multirow[t]{2}{*}{2009} & Mean & $700,774.714$ & $944,789.000$ & 6505.081 & $405,645.640$ \\
\hline & Std & $1,298,752.825$ & $1,740,176.613$ & $12,615.245$ & $753,260.447$ \\
\hline \multirow[t]{2}{*}{2010} & Mean & $806,223.566$ & $1,102,669.785$ & 7489.460 & $472,475.411$ \\
\hline & Std & $1,436,563.454$ & $1,967,965.962$ & $15,877.201$ & $866,849.209$ \\
\hline \multirow[t]{2}{*}{2011} & Mean & $967,551.584$ & $1,337,320.616$ & 9569.534 & $584,339.033$ \\
\hline & Std & $1,697,321.888$ & $2,359,165.301$ & $20,279.363$ & $1,053,892.337$ \\
\hline \multirow[t]{2}{*}{2012} & Mean & $1,118,001.058$ & $1,554,755.007$ & $10,071.158$ & $690,075.727$ \\
\hline & Std & $1,900,736.255$ & $2,698,968.348$ & $21,186.040$ & $1,223,147.129$ \\
\hline \multirow[t]{2}{*}{2013} & Mean & $1,284,507.821$ & $1,791,613.514$ & $11,344.126$ & $797,568.267$ \\
\hline & Std & $2,203,224.114$ & $3,136,658.019$ & $23,135.844$ & $1,437,350.575$ \\
\hline \multirow[t]{2}{*}{2014} & Mean & $1,468,736.402$ & $2,055,353.169$ & $13,366.877$ & $914,917.373$ \\
\hline & Std & $2,542,227.980$ & $3,657,025.292$ & $28,479.543$ & $1,681,956.063$ \\
\hline
\end{tabular}

input efficient. Then we utilize the probabilistic approach by Cazals et al. (2002) and define bank's production set in (1) as: 


$$
\Omega=\left\{(v, \kappa) \in R_{+}^{p+q} \mid \Phi_{Y \mathrm{~K}}(v, \kappa)>0\right\},
$$

where $\Phi_{Y \mathrm{~K}}(v, \kappa)=\operatorname{Prob}(Y \leq v, \mathrm{~K} \geq \kappa)$, implying free disposability of $\Omega$. Then we can retrieve the following conditional probability $\Phi_{Y \mid \mathrm{K}}=\operatorname{Prob}(Y \leq v \mid \mathrm{K} \geq \kappa)$ and we consider that:

$$
\Phi_{Y \mathrm{~K}}(v, \kappa)=\Phi_{Y \mid \mathrm{K}}(v \mid \kappa) \Lambda_{\mathrm{K}}(\kappa),
$$

where $\Lambda_{\mathrm{K}}(\kappa)=\operatorname{Prob}(\mathrm{K} \geq \kappa)$. Then the banks' efficiency score at $\left(v_{0}, \kappa_{0}\right)$ level can be redefined as:

$$
\vartheta\left(v_{0}, \kappa_{0}\right)=\inf \left\{\vartheta>0 \mid \Phi_{Y \mid \mathrm{K}}\left(\vartheta v_{0} \mid \kappa_{0}\right)>0\right\},
$$

where the empirical version of $\Phi_{Y \mid \mathrm{K}}(v \mid \kappa)$ can be obtained from:

$$
\hat{\Phi}_{Y \mid \mathrm{K}}(v \mid \kappa)=\frac{\sum_{i=1}^{n} I\left(Y_{i} \leq v, \mathrm{~K}_{i} \geq \kappa\right)}{\sum_{i=1}^{n} I\left(\mathrm{~K}_{i} \geq \kappa\right)} .
$$

As has been introduced by Mastromarco and Simar (2015), ${ }^{2}$ we can consider time $T$ as a conditional variable and for every time period $t$ (years in our case) we can define $\Omega_{t}$ as the support of the following conditional probability $\Phi_{Y \mid \mathrm{K}}^{t}=\operatorname{Prob}(Y \leq v \mid \mathrm{K} \geq \kappa, T=t)$ and define $\Omega_{t}$ as:

$$
\Omega_{t}=\left\{(v, \kappa) \in R_{+}^{p+q} \mid \Phi_{Y \mathrm{~K}}^{t}(v, \kappa)>0\right\} .
$$

At a specific time period, let $\left(v_{0}, \kappa_{0}\right)$ denote bank's input and output levels. Then the time dependent efficiency score can be obtained from:

$$
\vartheta_{t}\left(v_{0}, \kappa_{0}\right)=\inf \left\{\vartheta>0 \mid\left(\vartheta v_{0}, \kappa_{0}\right) \in \Omega_{t}\right\}=\inf \left\{\vartheta>0 \mid \Phi_{Y \mid \mathrm{K}}^{t}\left(\vartheta v_{0} \mid \kappa_{0}\right)>0\right\} .
$$

As presented by Daouia and Simar (2007), we can retrieve the unconditional and the time dependent robust $\alpha$-quantile frontiers for any $a \in(0,1)$ from:

$$
\begin{gathered}
\vartheta_{a}\left(v_{0}, \kappa_{0}\right)=\inf \left\{\vartheta>0 \mid \Phi_{Y \mid \mathrm{K}}\left(\vartheta v_{0} \mid \kappa_{0}\right)>1-\alpha\right\}, \\
\vartheta_{t, a}\left(v_{0}, \kappa_{0}\right)=\inf \left\{\vartheta>0 \mid \Phi_{Y \mid \mathrm{K}}^{t}\left(\vartheta v_{0} \mid \kappa_{0}\right)>1-\alpha\right\} .
\end{gathered}
$$

We consider the time effect on banks' input oriented measures (both for the full $^{3}$ and robust frontiers) by constructing the following ratios from the conditional and unconditional measures:

\footnotetext{
2 For computational issues on smoothing techniques applied, see Bădin et al. (2010, 2019).

3 In order to account for banks' scale effects, we apply for the estimation of the unconditional and conditional frontiers' data envelopment analysis (DEA) estimators under the variable returns to scale (VRS) (Banker et al. 1984).
} 


$$
Q=\frac{\vartheta_{t}\left(v_{0}, \kappa_{0}\right)}{\vartheta\left(v_{0}, \kappa_{0}\right)}, \quad Q_{\alpha}=\frac{\vartheta_{t, a}\left(v_{0}, \kappa_{0}\right)}{\vartheta_{a}\left(v_{0}, \kappa_{0}\right)}
$$

As has been explained in Bădin et al. (2012), by comparing the $Q$ ratios as a function of $T$ we capture the marginal effects of time on banks' shift of the frontier (i.e. banks' technological change levels). When we compare $Q_{\alpha}$ (for median $\alpha$ values, i.e. $\alpha=0.5)$, we investigate the effect of time on the distribution of banks' efficiency levels (i.e. technological catch-up). Given the adopted orientation, a decreasing nonparametric smooth regression line signifies an average positive effect of time (as if time acts as an extra free disposable input). In the opposite case, an increasing nonparametric smooth regression line signifies an average negative effect of time (as if time acts as an extra 'bad' output), whereas, a horizontal nonparametric smooth regression line indicates a neutral effect.

\subsection{Convergence Methodology: The Phillips and Sul (2007) Approach}

As a second step of our analysis, we investigate convergence within the panel of dynamic efficiency scores of 73 Indian banks, for which we utilize the convergence methodology of Phillips and Sul (2007). Given the scope of this study investigating the evolution of banks' time dependent efficiency over a 19-year period, the use of the Phillips and Sul method is perfectly suitable. In addition, this methodology is superior to the classical $\beta$-convergence approach (see Matousek et al. 2015 for a discussion). The applied approach accounts for transitional heterogeneity utilizing transition coefficients, $h_{i t}$, representing the bank's efficiency score share $y_{i t}$, in relation to the average efficiency score. Using the relative transition coefficients, the 'logt' test can be presented as:

$$
\log \frac{H_{1}}{H_{t}}-2 \log (\log t)=\alpha+\gamma \log t+u_{t}, \text { for } \mathrm{t}=T_{0}, \ldots, T
$$

In Eq. (12) $\gamma$ measures the convergence's magnitude and speed whereas $H_{t}=N^{-1} \sum_{i=1}^{N}\left(h_{i t}-1\right)^{2}$. The convergence is indicated when $\gamma \geq 2$, whereas $\gamma$ values $2>\gamma \geq 0$ imply conditional convergence. Using the log $t$ test, we can determine the existence of convergence. In addition, Phillips and Sul (2007, 2009) propose a clustering mechanism tool which identifies the presence of club formation that may be present in the absence of whole panel convergence. The clustering test, as detailed in Phillips and Sul (2007), is a 4-step procedure which consists of repeated $\log t$ tests that start with the formation of a core club, and new members are subsequently added or dropped to identify any convergent or divergent clubs. 


\section{Empirical Findings}

\subsection{Time Dependent Efficiency Scores}

As has been explained in the methodology section, we evaluate banks' efficiency levels under the assumption of VRS in order to include possible scale effects among the evaluated banks over the entire period. Table 2 presents the original efficiency estimates ranked by their VRS efficiency values. Looking at the top 15 best performing banks, the results show that almost half of them are state-owned banks, namely IDBI Bank Ltd, Bank of India, State Bank of India, Bank of Baroda, Union Bank of India, Canara Bank, and Punjab National Bank. Six of the top performers are private banks; Kotak Mahindra Bank Ltd, ICICI Bank Ltd, City Union Bank Ltd, Karur Vysya Bank Ltd, Shamrao Vithal Co-op Bank Ltd and Federal Bank Ltd while there is only one cooperative bank (Bharat Co-op. Bank (Mumbai) Ltd, and one foreign bank (Bank of Nova Scotia) among the top. In contrast, we identify the majority of the worst performers as banks with foreign ownership namely; HSBC Ltd, DBS Bank Ltd, Societe Generale, Mashreq bank Plc, Barclays Bank Plc, Abu Dhabi Commercial Bank and HSBC Oman SAOG. Our findings support the earlier studies (Sanyal and Shankar 2011; Tabak and Tecles 2010) indicating higher efficiency levels for state-owned banks in relation to foreign-owned banks.

Moreover, Fig. 1 presents the density plots of the obtained efficiency estimates across selected years. ${ }^{4}$ Specifically Fig. 1a presents the efficiency density plots for the years 1996, 2000 and 2004, whereas, Fig. 1b for 2007, 2010 and 2014. As can be identified, during 1996 we have the twin peak phenomenon indicating that the mass of banks' efficiency levels was concentrated at 0.55 and 0.7 levels. However, during 2000 the mass was concentrated at 0.5 efficiency level and during 2004 at about 0.6 (Fig. 1a). When looking at Fig. 1b during the onset of Global Financial Crisis (GFC), we observe that the mass of banks' efficiency levels was at 0.75 level. However, during the GFC (i.e. 2011), there is an indication of an overall increase in banks' efficiency levels with the mass located at 0.8. Finally, for the year 2014 we observe a platykurtic distribution of banks' efficiency levels suggesting large variations within the efficiency estimates among the examined banks. This empirical finding suggests that we have a hetero-chronic effect of the GFC on the Indian banking industry. Hence, the impact of the GFC on the Indian banks was felt well after the crisis period in sharp contrast to EU/US banks.

Figure 2 presents diachronically banks' mean efficiency scores based on their ownership structure. The results reveal that up to 2004 and especially for the period 1996-2002, banks' efficiency levels were fairly similar with privateowned and cooperative banks showing higher efficiency levels. However, after 2002 and especially for the period post-2005 the overall picture changes. Stateowned banks which started off as the laggards in terms of efficiency at the outset quickly moved to dominate the Indian banking sector with the highest efficiency

\footnotetext{
${ }^{4}$ The density plots of the VRS efficiency estimated for all the years are available upon request.
} 


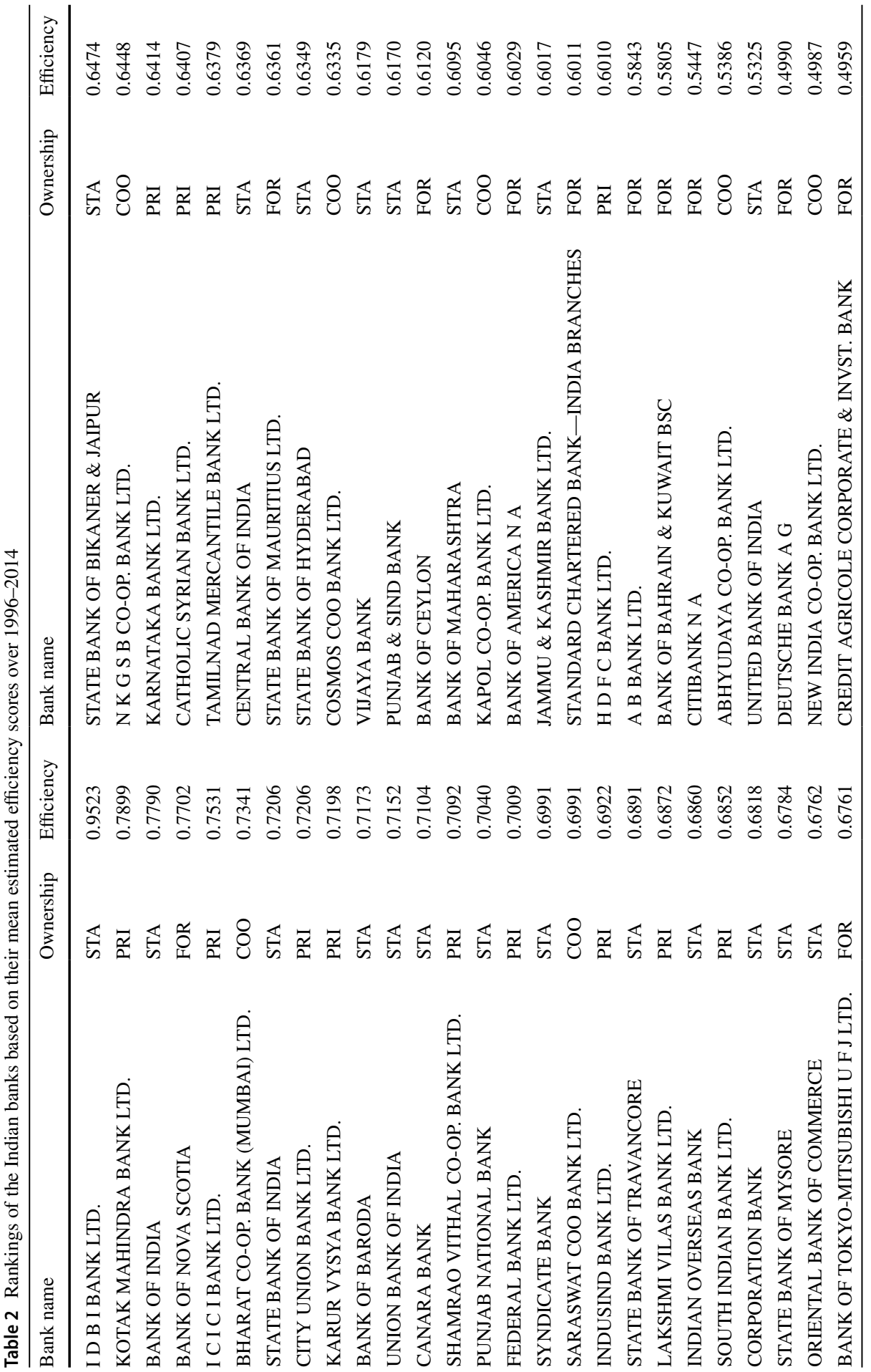




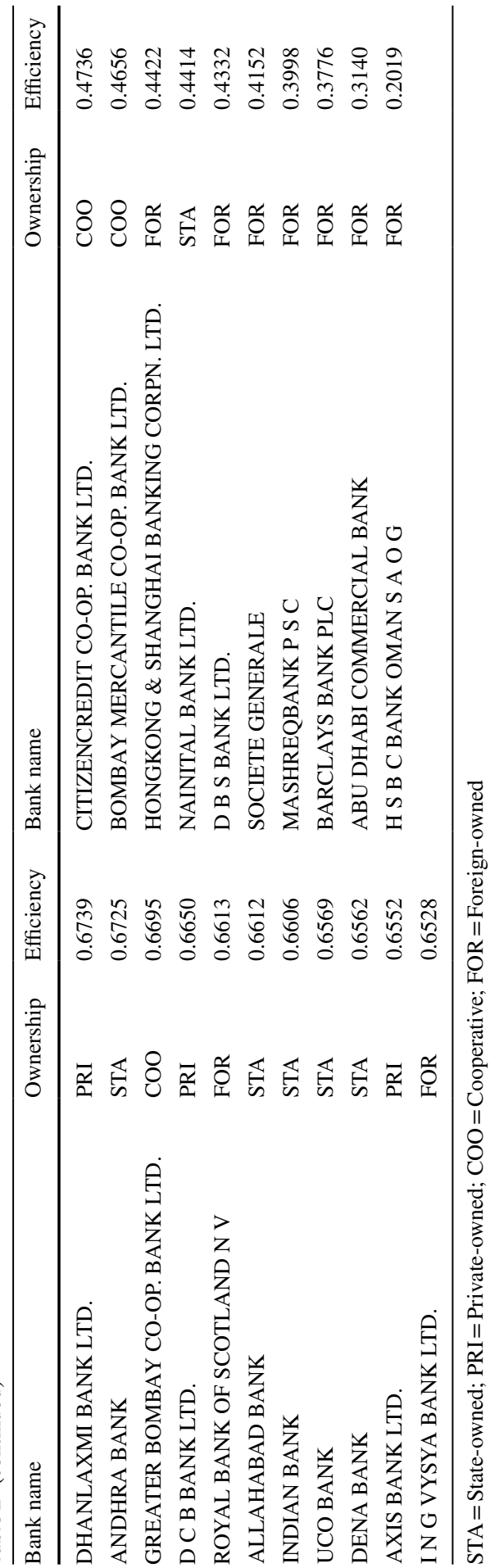



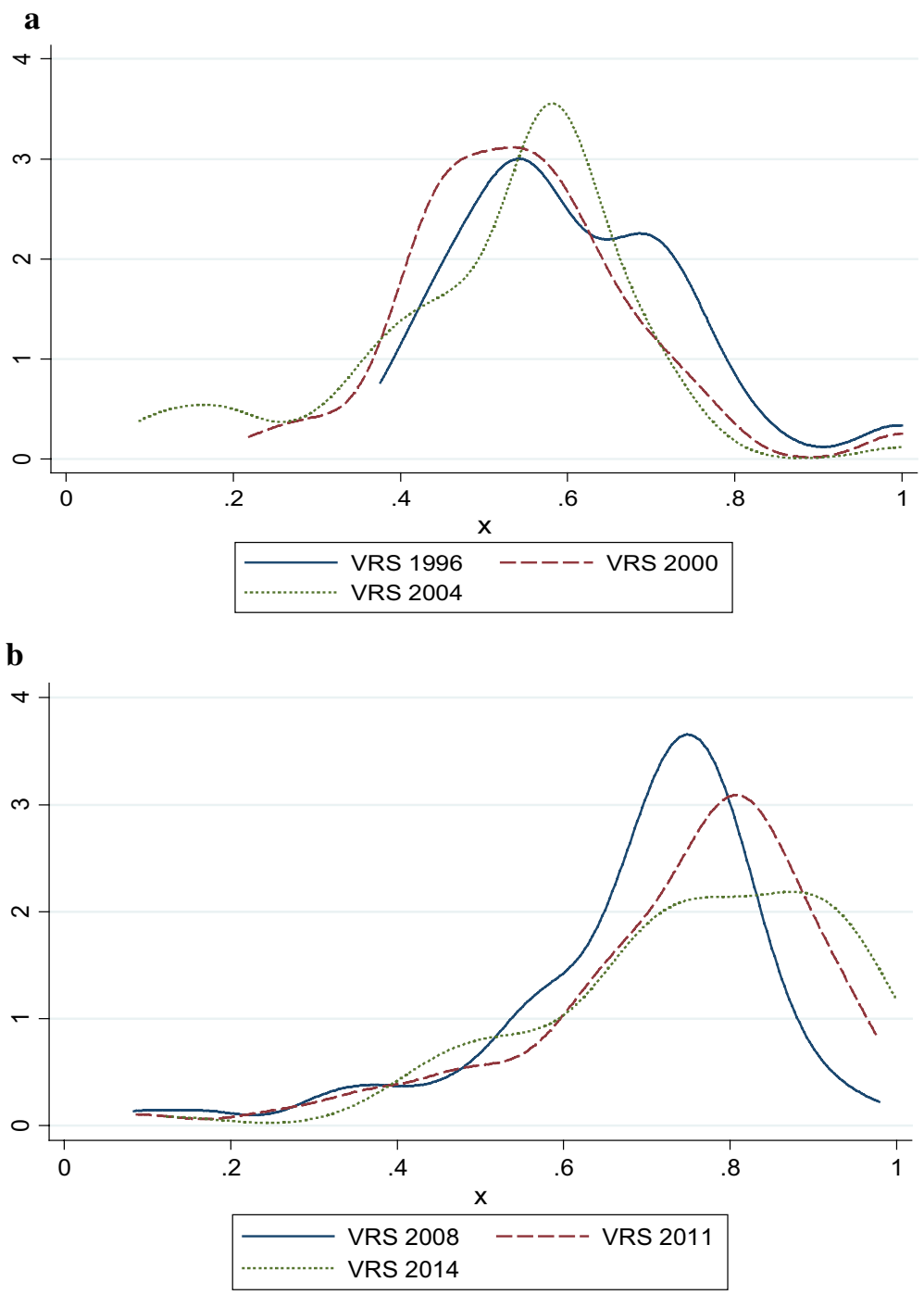

Fig. 1 Kernel density plots of the efficiency scores

estimates. Moreover, foreign-owned banks are reported to have the lowest efficiency levels, especially during the GFC period.

Finally, in Fig. 3, we present the findings from the second stage nonparametric regression analysis comparing the $Q$ ratios as a function of time. As it has been described by Jeong et al. (2010), we utilize a cross-validated local linear estimator (also see, Li and Racine 2004). The subfigures 'a', 'c', 'e', 'g' and 'i' present graphically the effect of time on banks' technological shift, whereas, the 


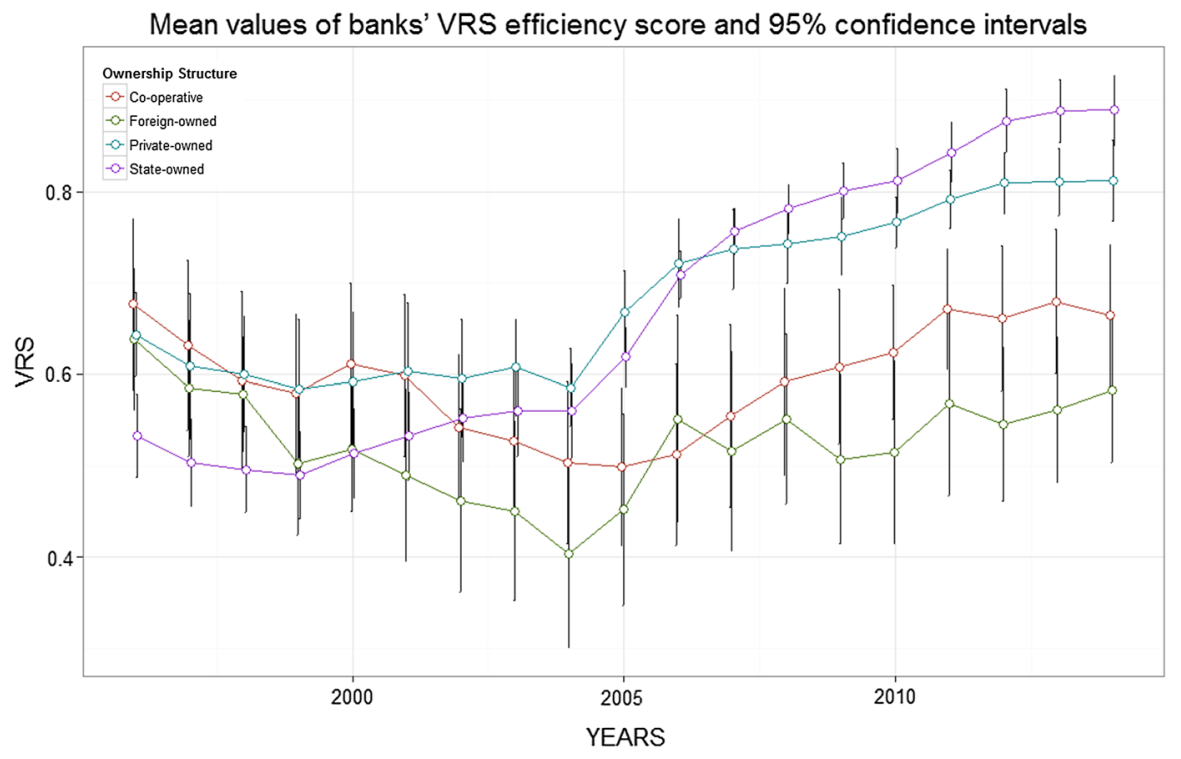

Fig. 2 Diachronical representations of banks' efficiency scores based on their ownership structure

subfigures 'b', 'd', 'f', 'h' and 'k' present the effect of time on bank's technological catch-up. ${ }^{5}$

When we examine the entire sample subfigures ( $a$ and $b$ ) we observe a negative effect of time on change in banks' technological frontier for the period 1996-2004. This negative effect is illustrated with an increasing nonparametric line. However, after 2004 and for the rest of the examined period the effect becomes positive as demonstrated by a decreasing nonparametric line. In a similar way, a negative effect of time on banks' catch-up levels is observed for the period 1996-2002, whereas, the effect becomes positive after this point. When we consider foreign-owned banks, we observe a similar phenomenon but with different turning points. For technological change, the effect is negative just before the start of the GFC. However, the effect of time on foreign owned banks' technological frontier becomes positive beyond this time point (Fig. 3c). However, for the case of technological catch-up (Fig. 3d) we observe that the negative effect on foreign banks' technological catch-up levels is more pronounced up to 2011, which, after that time point slightly turns to be positive signifying a recovery time point after GFC. For the private-owned banks, we observe a negative impact of time on their technological change up to early 2000's (Fig. 3e). After that point and for the period 2001-2010, the effect turns positive and then becomes negative. Moreover, the effect of time on private-owned banks' technological catch-up levels is reported to be negative (Fig. 3f).

\footnotetext{
5 The estimated nonparametric line is presented in those plots alongside $95 \%$ estimated bootstrap intervals (Hayfield and Racine 2008).
} 
Fig. 3 Time effects of technological change and technological catch-up
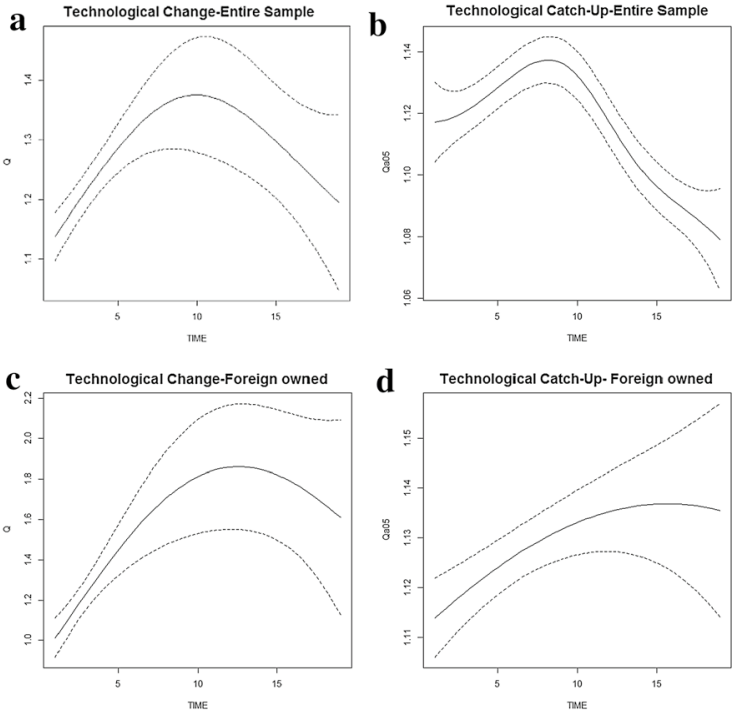

d Technological Catch-Up- Foreign owned
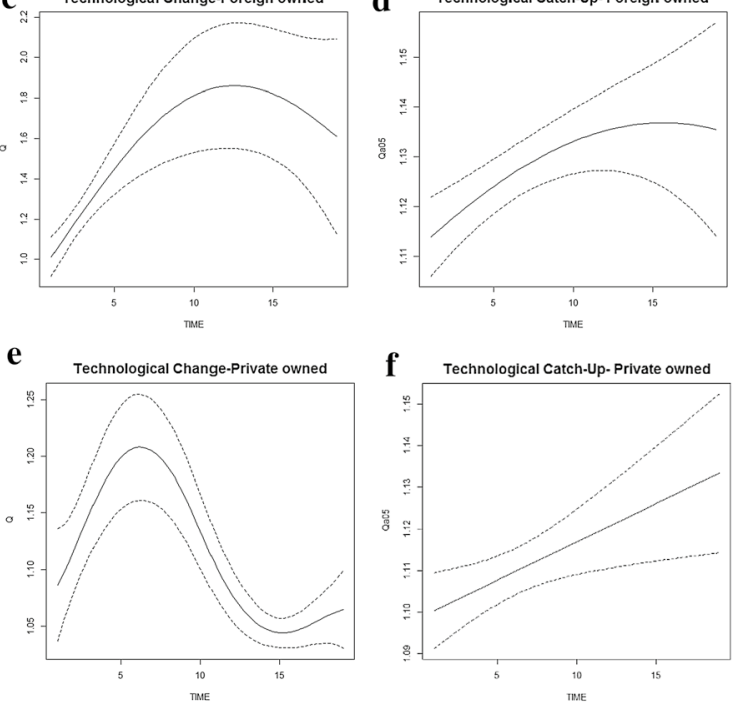

f Technological Catch-Up- Private owned
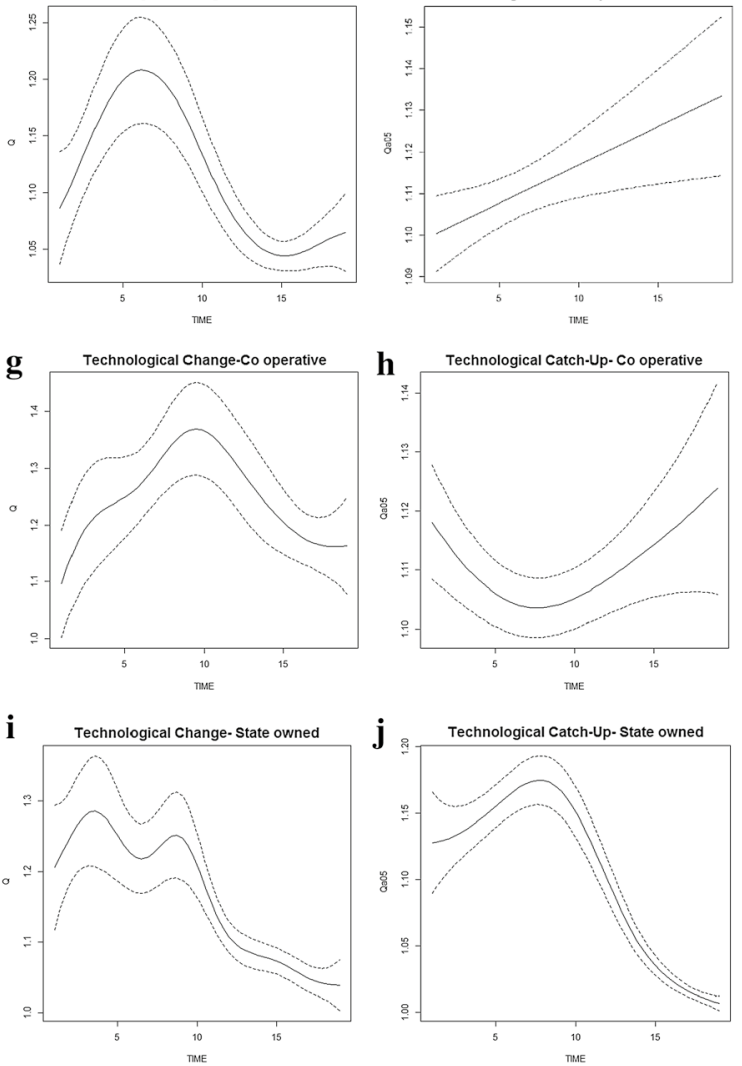
Table 3 Phillips and Sul $\log t$ convergence test on the inputoriented efficiency scores

\begin{tabular}{llr}
\hline & $\gamma$ & \multicolumn{1}{l}{$t$-stat } \\
\hline All banks & -1.026 & $-11.061^{*}$ \\
State-owned banks & -0.657 & $-2.991^{*}$ \\
Private owned banks & -1.366 & $-4.440^{*}$ \\
Cooperatives & -1.758 & $-3.127^{*}$ \\
Foreign-owned & -1.042 & $-4.600^{*}$ \\
\hline
\end{tabular}

*Indicates rejection of the null hypothesis of convergence at 5\% significance level

When we consider the case of cooperative banks', we can observe a nonlinear negative effect for the period 1996-2005 on their technological change levels (Fig. 3g). However, for the rest of the period the effect turns positive. In contrast when we examine the time effects on their technological catch-up, we observe a positive effect over the period 1996-2002, whereas, a negative effect over the period 2002-2014 is noted (Fig. 2h). Finally, for state-owned banks, it is evident that during 1996-2004 the effect of time on banks' technological change is mixed as reflected in a highly nonlinear nonparametric regression line. However, for the rest of the period the effect is positive with a steeper negative line during the period 2004-2007. This finding suggests that the gains on state-owned banks' technological change levels were greater before the GFC period in contrast with the period 2007-2014, in which, again the effects are positive, but, the gains are less as denoted by a less steep negative nonparametric regression line (Fig. 3i). Finally, Fig. 3k signifies nonlinear effects of time on state-owned banks' technological catch-up levels. It must be noted that for the period 1996-2002, the effect was negative. However, after that year the effect was positive.

\subsection{Convergence Results}

In order to analyse whether convergence in time-dependent efficiency levels is present among the four main types of banks that co-exist in India following the banking reforms of 1991 and 1998, we implement Phillips and Sul (2007)'s panel convergence and club clustering methods. Our panel of 73 banks is categorised on the basis of the ownership structure i.e. (i) all banks, (ii) state-owned, (iii) private, (iv) cooperatives and (v) foreign banks to encapsulate the effects of the widespread banking reforms. The $\log t$ test results are tabulated in Table 3 and show that the null hypothesis of convergence is rejected for all 4 panels at the $5 \%$ significance level for both periods. These results point to two main conclusions. Firstly, the lack of group convergence over the period 1996-2014 suggests that heterogeneity in Indian banking efficiency is prevalent and secondly, bank structure as a common basis does not seem to be a driving factor for convergence in efficiency. However, as in Phillips and Sul (2009), the presence of club convergence could be the reason why the null of overall convergence is rejected as the $\log t$ regression test has power against such cases. 


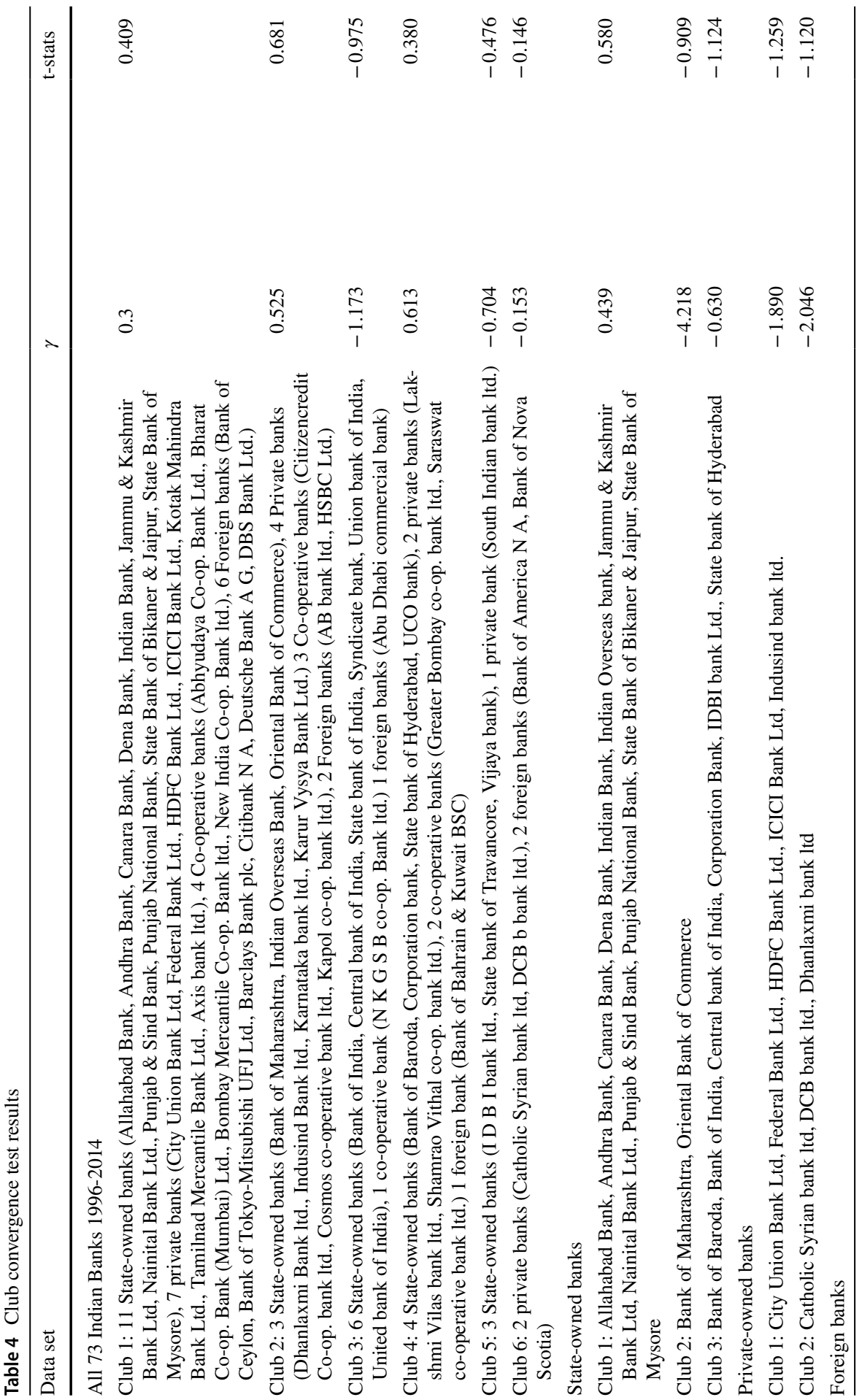




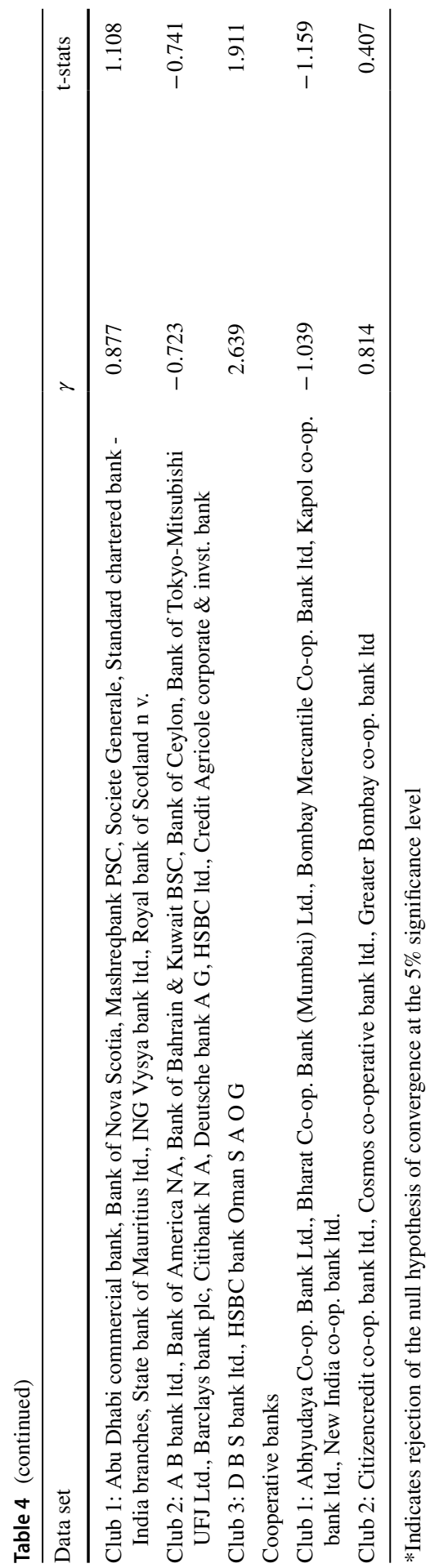


The club convergence results confirm that this is indeed the case as we find the overwhelming presence of several clusters of convergence, as presented in Table 4 across all 4 types of banks. For the whole panel of 73 banks, we identify 6 clusters, with each cluster typically regrouping all 4 types of banks. The first club is the biggest comprising 11 state-owned banks, 7 private banks, 4 co-operative banks and 6 foreign banks. However, the speed of convergence for all 6 clusters is slow with $\gamma$ ranging between 0.3 and -1.173 . We therefore note that the type of convergence relates to the rate of change in efficiency levels as $\gamma<2$. The other 5 club formations have smaller number of banks and we note weak convergence rates in 2 of the clusters.

When we test for club convergence among each type of bank ownership, we find the presence of up to 3 convergent clusters. The composition of the clusters very closely mirrors those of the clubs obtained when the whole panel is tested so there is consistency in the formation of the clubs. This finding suggests that the type of bank ownership is, partly, a determining factor in efficiency of Indian banks. Other driving factors are likely to be other bank-specific factors such as geographical location. In addition, two other observations can be made from the club convergence results. Firstly, for the group of private banks, we identify very weak convergence $(\gamma=-1.890,-2.046)$. This would suggest that heterogeneity in efficiency levels for private banks is present throughout the period 1996-2014. Secondly, the panel of foreign banks exhibit the highest speed of convergence amongst all panels $(\gamma=2.639)$. Again the ownership structure is likely to be a driving force. Overall, our club convergence results, to some extent, tally with those of Kumar and Gulati (2009) and Kumar (2013) who found the presence of $\beta$-convergence for the case of Indian public sector banks' efficiency levels.

\section{Conclusions}

After having undergone a major transformation since the financial reforms were introduced in the 1990s, the banks in India now comprise of state-run, private, foreign and cooperative banks. In this study, we analysed the time dependent efficiency scores for a panel of 73 banks over the period 1996-2014. Interestingly we identify several state-owned banks being the most efficient in the panel, while the majority of the worst performers are foreign banks. However, this was not always the case as during the period 1996-2002, as all types of banks' efficiency levels were fairly similar with privately-owned and cooperative banks showing higher levels of efficiency. However, after 2002 and especially during the post-2005 period, state-owned banks which started off as the less efficient banks in the panel overtook all other types of banks to assert themselves as the top performers with regard to efficiency.

Our results also indicate an increase in bank efficiency during the global financial crisis, as Indian banks continue to have limited exposure to global markets due to the country's closed capital account. However, for the year 2014, we find large variations in the efficiency levels for the banks and we attribute the diversity in the estimates to the growth slowdown around that time. The negative impact of the crisis was quite significant for the foreign banks. Overall, we note that the banking sector in India is resilient and has weathered the financial crisis differently to their 
counterparts in other emerging and developed economies. Looking at the impact of time on banks' technological change and catch-up levels, we observe a negative effect of time on banks' technological change between 1996 and 2004, and on banks' technological catch-up during 1996-2002. Since 2002 until the end of 2014, we observe a positive effect of time on banks' technological change and catch-up. This no doubt coincides with massive investment in technology, especially by stateowned banks.

Convergence tests on the efficiency of banks reveal that although overall group convergence is absent for the period 1996-2014, club convergence is identified among all four types of banks throughout the sample period. This is evident from the large number of convergent clusters made up of banks from all 4 types of ownership. We find that the composition of the clusters is partly driven by the ownership structure.

With the Indian economy expected to undergo further transformation with policies directed at being more business-conducive and with better targeting of inflation reflecting macroeconomic stability, the Indian banking sector finds itself on the brink of further transformation, including the process of consolidation of stateowned banks. Demand for better services, the growing spread of mobile and internet banking, the need to invest in technology upgrading and innovation are some of the new and continuing challenges that the banks will face as the economy lurches ahead. Going forward, Indian banks are likely to face further pressure on asset quality and capitalisation as the volume of NPLs in sectors facing difficulties is likely to increase, adding to credit risks. In addition, the implementation of Basel III poses further challenges with capital demand expected to rise. Banks with weak capitalisation will find themselves in more vulnerable position. However, the path ahead for Indian banks will continue to further depend on government's capital injections and financial support which will undoubtedly have a direct impact on bank performance.

Acknowledgements The authors would like to thank the editor of this journal for two rounds of rewriting on an earlier version of this paper. We are also thankful to Roman Matousek for his useful comments in the early stage of this work. We are solely responsible for any error that might yet remain.

Open Access This article is licensed under a Creative Commons Attribution 4.0 International License, which permits use, sharing, adaptation, distribution and reproduction in any medium or format, as long as you give appropriate credit to the original author(s) and the source, provide a link to the Creative Commons licence, and indicate if changes were made. The images or other third party material in this article are included in the article's Creative Commons licence, unless indicated otherwise in a credit line to the material. If material is not included in the article's Creative Commons licence and your intended use is not permitted by statutory regulation or exceeds the permitted use, you will need to obtain permission directly from the copyright holder. To view a copy of this licence, visit http://creativecommons.org/licen ses/by/4.0/.

\section{References}

Ahamed, M. M., \& Mallick, S. K. (2017a). Does regulatory forbearance matter for bank stability? Evidence from creditors' perspective. Journal of Financial Stability, 28, 163-180.

Ahamed, M. M., \& Mallick, S. K. (2017b). House of restructured assets: How do they affect bank risk in an emerging market? Journal of International Financial Markets, Institutions and Money, 47, 1-14. 
Bădin, L., Daraio, C., \& Simar, L. (2010). Optimal bandwidth selection for conditional efficiency measures: A data-driven approach. European Journal of Operational Research, 201(2), 633-640.

Bădin, L., Daraio, C., \& Simar, L. (2012). How to measure the impact of environmental factors in a nonparametric production model? European Journal of Operational Research, 223(3), 818-833.

Bădin, L., Daraio, C., \& Simar, L. (2019). A bootstrap approach for bandwidth selection in estimating conditional efficiency measures. European Journal of Operational Research, 277(2), 784-797.

Banker, R. D., Charnes, A., \& Cooper, W. W. (1984). Some models for estimating technical and scale inefficiencies in DEA. Management Science, 30(9), 1078-1092.

Berger, A. N., \& Humphrey, D. B. (1997). Efficiency of financial institutions: International survey and directions for future research. European Journal of Operational Research, 98, 175-212.

Berger, N. A., \& Mester, L. J. (1997). Inside the black box: What explains differences in the efficiencies of financial institutions? Journal of Banking \& Finance, 21, 895-947.

Bhattacharyya, A., \& Pal, S. (2013). Financial reforms and technical efficiency in Indian commercial banking: A generalized stochastic frontier analysis. Review of Financial Economics, 22, 109-117.

Bhaumik, S., \& Dimova, R. (2004). How important is ownership in a market with level playing field? The Indian banking sector revisited. Journal of Comparative Economics, 32, 165-180.

Casu, B., Ferrari, A., \& Zhao, T. (2013). Regulatory reform and productivity change in Indian banking. Review of Economics and Statistics, 95, 1066-1077.

Cazals, C., Florens, J. P., \& Simar, L. (2002). Nonparametric frontier estimation: A robust approach. Journal of Econometrics, 106(1), 1-25.

Chen, Z., Tzeremes, P., \& Tzeremes, N. G. (2018). Convergence in the Chinese airline industry: A Malmquist productivity analysis. Journal of Air Transport Management, 73, 77-86.

Cordero, J. M., Polo, C., Santín, D., \& Simancas, R. (2018). Efficiency measurement and cross-country differences among schools: A robust conditional nonparametric analysis. Economic Modelling, 74, 45-60.

Daouia, A., \& Simar, L. (2007). Nonparametric efficiency analysis: A multivariate conditional quantile approach. Journal of Econometrics, 140(2), 375-400.

Daraio, C., \& Simar, L. (2005). Introducing environmental variables in nonparametric frontier models: A probabilistic approach. Journal of Productivity Analysis, 24(1), 93-121.

Daraio, C., \& Simar, L. (2007). Conditional nonparametric frontier models for convex and nonconvex technologies: A unifying approach. Journal of Productivity Analysis, 28(1-2), 13-32.

Daraio, C., Simar, L., \& Wilson, P. W. (2018). Central limit theorems for conditional efficiency measures and tests of the 'separability' condition in non-parametric, two-stage models of production. The Econometrics Journal, 21(2), 170-191.

Das, A., \& Ghosh, S. (2006). Financial deregulation and efficiency: An empirical analysis of Indian banks during the post reform period. Review of Financial Economics, 15, 193-221.

Das, A., \& Kumbhakar, S. C. (2012). Productivity and efficiency dynamics in Indian banking: An input distance function approach incorporating quality of inputs and outputs. Journal of Applied Econometrics, 27, 205-234.

Degl'Innocenti, M., Kourtzidis, S. A., Sevic, Z., \& Tzeremes, N. G. (2017). Investigating bank efficiency in transition economies: A window-based weight assurance region approach. Economic Modelling, 67, 23-33.

Drake, L., \& Hall, M. J. B. (2003). Efficiency in Japanese banking: An empirical analysis. Journal of Banking \& Finance, 27, 891-917.

Fujii, H., Managi, S., \& Matousek, R. (2014). Indian bank efficiency and productivity changes with undesirable outputs: A disaggregated approach. Journal of Banking \& Finance, 38, 41-50.

Fukuyama, H., \& Matousek, R. (2011). Efficiency of Turkish banking: two-stage network system. Variable returns to scale model. Journal of International Financial Markets, Institutions and Money, 21, 75-91.

Gearhart, R. S., III, \& Michieka, N. M. (2018). A comparison of the robust conditional order-m estimation and two stage DEA in measuring healthcare efficiency among California counties. Economic Modelling, 73, 395-406.

Hayfield, T., \& Racine, J. S. (2008). Nonparametric econometrics: The np package. Journal of Statistical Software, 27(5), 1-32.

Jeong, S. O., Park, B. U., \& Simar, L. (2010). Nonparametric conditional efficiency measures: Asymptotic properties. Annals of Operations Research, 173, 105-122.

Kumar, S. (2013). Banking reforms and the evolution of cost efficiency in Indian public sector banks. Economic Change and Restructuring, 46, 143-182. 
Kumar, S., \& Gulati, R. (2010). Measuring efficiency, effectiveness and performance of Indian public sector banks. International Journal of Productivity and Performance Management, 59, 51-74.

Kumbhakar, S., \& Sarkar, S. (2003). Deregulation, ownership, and productivity growth in the banking industry: Evidence from India. Journal of Money, Credit, and Banking, 35, 403-414.

Li, Q., \& Racine, J. (2004). Cross-validated local linear nonparametric regression. Statistica Sinica, 14, 485-512.

Mallick, S., Matousek, R., \& Tzeremes, N. G. (2016). Financial development and productive inefficiency: A robust conditional directional distance function approach. Economics Letters, 145, 196-201.

Mastromarco, C., \& Simar, L. (2015). Effect of FDI and time on catching up: New insights from a conditional nonparametric frontier analysis. Journal of Applied Econometrics, 30(5), 826-847.

Mastromarco, C., \& Simar, L. (2018). Globalization and productivity: A robust nonparametric world frontier analysis. Economic Modelling, 69, 134-149.

Matousek, R., Rughoo, A., Sarantis, N., \& Assaf, A. G. (2015). Bank performance and convergence during the financial crisis: Evidence from the 'old' European Union and Eurozone. Journal of Banking \& Finance, 52, 208-216.

McKillop, D. G., Glass, J. C., \& Morikawa, Y. (1996). The composite cost function and efficiency in giant Japanese banks. Journal of Banking \& Finance, 20, 1651-1671.

Phillips, P. C. B., \& Sul, D. (2007). Transition modelling and econometric convergence tests. Econometrica, 75, 1771-1855.

Phillips, P. C. B., \& Sul, D. (2009). Economic transition and growth. Journal of Applied Econometrics, 24, 1153-1185.

Sahoo, B., \& Tone, K. (2009). Radial and non-radial decompositions of profit change: With an application to Indian banking. European Journal of Operational Research, 196, 1130-1146.

Sanyal, P., \& Shankar, R. (2011). Ownership, competition, and bank productivity: An analysis of Indian banking in the post-reform period. International Review of Economics and Finance, 20, 225-247.

Sarkar, J., Sarkar, S., \& Bhaumik, S. (1998). Does ownership always matter? Evidence from the Indian banking industry. Journal of Comparative Economics, 26, 262-281.

Sealey, C. W., \& Lindley, J. T. (1977). Inputs, outputs, and a theory of production and cost at depository financial institutions. Journal of Finance, 32, 1251-1266.

Sensarma, R. (2008). Deregulation, ownership and profit performance of banks: Evidence from India. Applied Financial Economics, 18, 1581-1595.

Simar, L., \& Wilson, P. W. (2007). Estimation and inference in two-stage, semiparametric models of production processes. Journal of Econometrics, 136, 31-64.

Simar, L., \& Wilson, P. W. (2011). Two-stage DEA: Caveat emptor. Journal of Productivity Analysis, 36, 205-218.

Tabak, B. M., \& Tecles, P. L. (2010). Estimating a Bayesian stochastic frontier for the Indian banking system. International Journal of Production Economics, 125, 96-110.

Tzeremes, N. G. (2015). Efficiency dynamics in Indian banking: A conditional directional distance approach. European Journal of Operational Research, 240(3), 807-818.

Tzeremes, N. G. (2019). Technological change, technological catch-up and export orientation: Evidence from Latin American Countries. Journal of Productivity Analysis, 52(1-3), 85-100.

Publisher's Note Springer Nature remains neutral with regard to jurisdictional claims in published maps and institutional affiliations.

\section{Affiliations}

\section{Sushanta Mallick ${ }^{1}$ (D) Aarti Rughoo ${ }^{2} \cdot$ Nickolaos G. Tzeremes $^{3} \cdot$ Wei Xu $^{4}$}

Aarti Rughoo

a.rughoo@herts.ac.uk

Nickolaos G. Tzeremes

bus9nt@econ.uth.gr 
Wei Xu

wei.xu@ryerson.ca

1 School of Business and Management, Queen Mary University of London, Mile End Road, London E1 4NS, UK

2 Hertfordshire Business School, University of Hertfordshire, Hatfield AL10 9AB, UK

3 Department of Economics, University of Thessaly, 28th October Street, 38333 Volos, Greece

4 Department of Mathematics, Ryerson University, Toronto, Canada 